\title{
Various English Literacy Activities in Bilingual Primary School
}

\section{P.I. Puspitasari ${ }^{1 *}$, N.N. Padmadewi ${ }^{2}$, L.P.E.S. Dewi ${ }^{3}$}

1,2,3 English Language Education, Post-Graduate Program, Ganesha University of Education, Singaraja, Indonesia

\author{
A R T I C L E I N F O \\ Article history: \\ 25 December 2020 \\ Received in revised form \\ 12 January 2021 \\ Accepted 02 February \\ 2021 \\ Available online 25 \\ Pebruari 2021 \\ Kata Kunci: \\ Aktivitas Literasi, \\ Bilingual, Sekolah Dasar \\ Keywords: \\ literacy activities, \\ bilingual, primary school
}

\begin{abstract}
A B S T R A K
Hasil dari Program Asesmen Siswa Internasional menunjukkan bahwa kemampuan literasi yang dimiliki siswa Indonesia berada dalam level rendah. Penelitian ini bertujuan untuk menginvestigasi kegiatan literasi berbahasa Inggris di sekolah dasar. Penelitian ini merupakan penelitian kualitatif dengan metode studi kasus. Tiga orang guru pengajar bahasa Inggris di kelas 1, 2, dan 3 dipilih sebagai subjek penelitian. Data dikumpulkan dengan menggunakan kuesioner, panduan wawancara, dan daftar cek. Prosedur pengumpulan data dilakukan dengan menyebarkan kuesioner, melakukan wawancara, dan melakukan pengamatan kelas. Data dianalisis dengan metode analisis data dari Cresswell yang terdiri dari organisasi data, koding, deskripsi dan menyusun tema, melaporkan temuan, menginterpretasi, dan memvalidasi data. Hasil dari penelitian ini menunjukkan bahwa ada delapan aktivtitas literasi, yaitu Directed Reading-Thinking Activity, membaca terbimbing, membaca dengan bantuan multimedia, berpikir nyaring, membaca nyaring, dikte, mengenal huruf, dan menulis. Penelitian ini memberikan gambaran tentang kegiatan literasi bahasa Inggris di Sekolah Dasar yang dilakukan oleh para guru. Oleh karena itu, disarankan kepada guru bahasa Inggris untuk mengajarkan literasi kepada siswa
\end{abstract} sejak usia dini karena literasi merupakan dasar penting untuk pembelajaran siswa di masa depan.

\begin{abstract}
A B S T R A C T
The results of Program of International Student Assessment show that the literacy skills of Indonesian students was in the low level. This study aims to investigate English literacy activities in elementary schools. This research is a qualitative research with a case study method. There were three English teachers who teach on the $1^{\text {st }}, 2^{\text {nd }}$, and $3^{\text {rd }}$ grade assigned as the subjects of this study. Data were collected using a questionnaire, interview guide, and checklist. The data collection procedure was carried out by distributing questionnaires, conducting interviews, and conducting classroom observations. Data were analyzed using data analysis methods from Cresswell which consisted of data organization, coding, description and developing themes, reporting findings, interpreting, and validating data. The results of this study indicate that there are eight literacy activities, namely Directed Reading-Thinking Activity, guided reading, reading with multimedia assistance, thinking aloud, reading aloud, dictating, recognizing letters, and writing. This study provides a description about English literacy activities in Primary School conducted by teachers. Therefore, a suggestion is directed to English teachers to teach literacy to students since the early age as literacy is an important basis for students' future learning.
\end{abstract}

\section{Introduction}

Literacy refers to the ability to identify, understand, create, and compute in various contexts (Montoya, 2018). It ranges from the basic ability to read, write, listen and comprehend, to higher skills where the learners are able to interpret and elaborate on what they have learnt (August \& Shanahan, 2010). Literacy is crucial because most educational process depend on literacy abilities and awareness as it is a means for students to know, understand, and apply the knowledge they get at school (Wiedarti et al., 2018). Through literacy, students are expected to be able to implement their knowledge or skills that they get in the school to their daily life (Harosid, 2017). Moreover, literacy has a good impact on students' learning competence, readiness, and attitude (Muhajang \& Pangestika, 2018; Padmadewi et al., 2020; Rittner, 2018). Literacy is important to be developed since the young age because young learners' brain are considered to develop faster than any other time of life (Hill, 2011; Rusu et al., 2017). Children's literacy skills are not affected by age; it is affected by exposure to literacy (Cetin et al., 2018). Therefore, it is important to expose children with literacy materials since the early ages. Artini (2017) emphasized that systematic exposures to literacy materials have significant positive impact on young students' literacy. 
The phenomenon of literacy in Indonesia shows that the students' literacy skill is lower than other countries. Based on the result of PISA in 2018, Indonesian students' literacy was on the $74^{\text {th }}$ position out of 79 countries, with score 371(OECD, 2018). It shows that Indonesian students had lack of literacy skills. Home parental involvement, students' perceptions of reading, lack of reading habit, school's lack of literacy development programs, and learning models are factors that affect the literacy of Indonesian students (Padmadewi \& Artini, 2018; Ratri, 2015; Wahyuni, 2014).

Considering this phenomenon, it is important to find suitable activities for children to develop their literacy. Several research has previously been conducted to describe activities that can improve students' literacy. A research by Dewi et al. (2018) found there were five literacy activities namely reading buddy, cooperative literacy program, interactive storytelling, reading respond journal and novel study were suitable activities for primary school students on the $3^{\text {rd }}, 4^{\text {th }}$, and $5^{\text {th }}$ grades. Moreover, Padmadewi et al. (2018) found several literacy-based activities namely Introductory Library Program, Newspaper Club, Empowering Houses, Cooperative Literacy, and Project-based Learning as the activities that could build students' literacy and character. In addition, Ayu et al. (2017) claimed the use of Interactive Read Aloud Instructional Strategy (IRAIS) was suitable for students of junior high school level. Despite a lot of research conducted on literacy previously, research on literacy activities on the younger students in primary school is rare to find. It is important to build literacy habit since the young age because habits are formed best since the young ages (Pérez-Ferra et al., 2020). Thus, it is urgent to investigate the classroom literacy activities that can build students' literacy in the early ages. In this case, on the $1^{\text {st }}, 2^{\text {nd }}$, and $3^{\text {rd }}$ grades.

This study aims to explore English literacy activities conducted in Jembatan Budaya Primary School, Bali. Jembatan Budaya is a bilingual school which concerns on students' literacy. It applies School Literacy Movement as instructed by the Indonesian government to build students' literacy habits. Specifically, for English language, the English teachers set a sort of literacy activities conducted in the classroom to build students' English literacy. The literacy activities were started from the first grade to build students' literacy habits.

\section{Method}

This study employed case study design which explores an activity, event, process, or individuals based on extensive data collection (Creswell, 2012). This study took place in Jembatan Budaya School located in Jalan Raya Kuta No. 1, Kuta, Bali. This school is one of "national plus" schools in Bali which uses English as a medium of daily communication. In this study, the researcher identified and described the literacy activities implemented on the $1^{\text {st }}, 2^{\text {nd }}$, and $3^{\text {rd }}$ grade. The samples were chosen purposefully to select research subjects who understand the central phenomenon in order to provide the data needed to answer the problems under investigation (Creswell, 2012). There were three English teachers assigned as the samples of this study. Those teachers teach English on the $1^{\text {st }}, 2^{\text {nd }}$, and $3^{\text {rd }}$ grades.

In this study, the data collection involved three sources of evidence, namely classroom observations, semi-structured interview with the teacher, and questionnaires. The researcher combined those mutiple methods or triangulation to assure the validity. As this study used qualitative research design, the data were analyzed descriptively through step proposed by Creswell (2012) namely organizing the data, coding, describing and developing themes, reporting the findings, interpreting, and validating the data. Firstly, after the data were gathered, they were organized based on its types, such as interview result, data from questionnaire, data from observation, photographs, or other visual materials. Then, in coding process, the data were transcribed. The codes were grouped together to form broader themes as the key findings of the study. The researcher then provided considerable description of the data to answer the research questions.

After the data were coded and analyzed for description and themes, the data were displayed in tables or figures and constructed narrative to explain what was found in response to the research questions. The researcher then compared the findings of the study to previous studies and literature to see how findings support or contradict the prior studies. Validation was done to make sure that the findings and interpretations are accurate through triangulation.

\section{Result and Discussion}

The school implemented primary literacy activities on the $1^{\text {st }}, 2^{\text {nd }}$, and $3^{\text {rd }}$ grades which characterized by the students' ability to decode words, comprehend a reading text, put words together to form simple sentences, develop ideas in logical progression, and write about topics of personal interest in various modes such as letters, stories, and poems (NCBD, 2014; Padmadewi \& Artini, 2018). There were various activities conducted by teachers in conducting English literacy activities in those grades, namely: 
Directed Reading - Thinking Activity (DRTA), guided reading, multimedia-assisted reading, thinking aloud, reading aloud, alphabet recognition, dictation, and writing. The summary of literacy activities and its topics are presented in Table 1.

Table 1. Summary of Literacy Activities Conducted at Jembatan Budaya Primary School

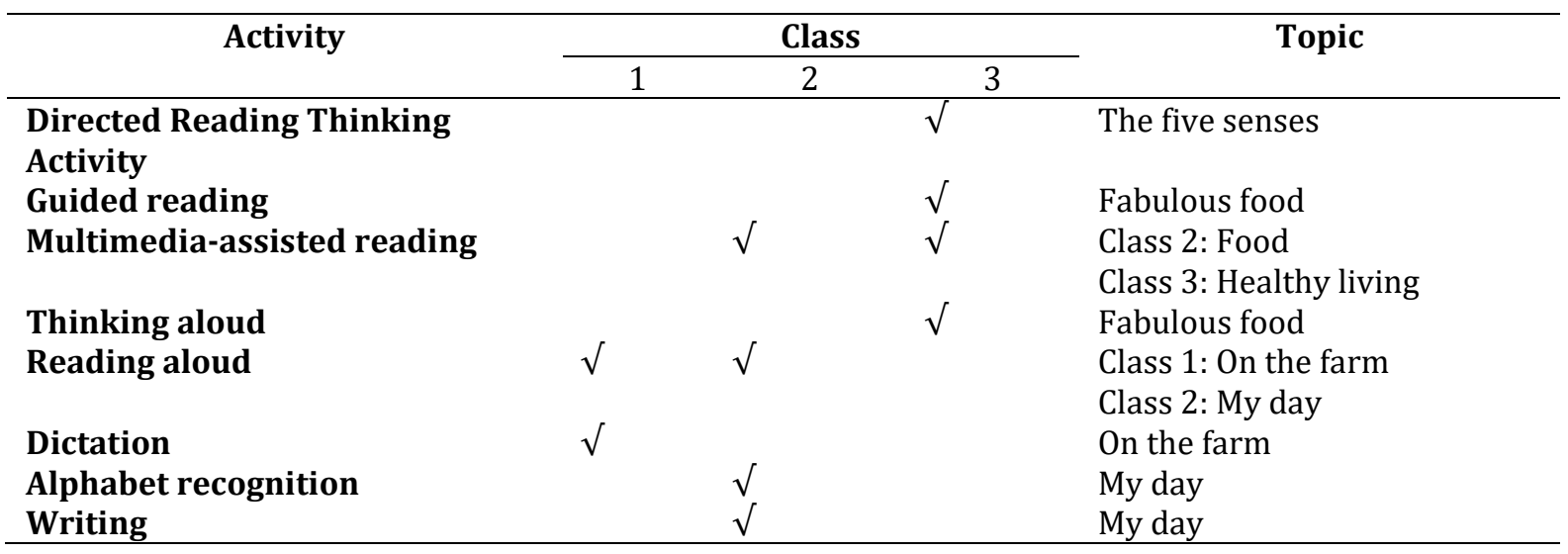

The English literacy activities conducted on the $1^{\text {st }}$ grade were reading aloud and dictation. Both activities were conducted under the same topic: "On the Farm". Further, the English literacy activities conducted on the $2^{\text {nd }}$ grade were multimedia-assisted reading, reading aloud, alphabet recognition, and writing. Those activities were conducted under two different topics: "Food" and "My Day". Moreover, the literacy activities conducted on the $3^{\text {rd }}$ grade were Directed Reading-Thinking Activity (DRTA), guided reading, multimedia-assisted reading, and thinking aloud. Those activities were conducted under various topics, they were: "The Five Senses", "Fabulous Food", and "Healthy Living".

Before implementing the activities in the classroom, the teachers did several preparation. Generally, the teachers coordinated with their team-teachers to decide the materials and learning objectives, developed lesson plan, and prepared teaching media in planning stage. Planning is a vital part in language instruction as it gives the lesson a framework; it helps teachers to think ahead of destination which they want their students to reach and how to get there (Harmer, 2007). It helps teachers to manage their time and decide what types of learning activities that will enable students to achieve the learning outcomes (Jensen, 2001; Nesari \& Heidari, 2014). The description of each literacy activity conducted at Jembatan Budaya Primary School is presented as follows.

\section{Directed Reading - Thinking Activity (DRTA)}

The Directed Reading Thinking Activity is a reading activity that guides students in making predictions of a text and then reading to confirm or refute their predictions. This reading activity involves three phases, namely: Direct, Reading, and Thinking (Reading Rockets, 2019). In the Direct phase, the teacher directed students to arise their knowledge about the text (in this case, the five senses) by asking several questions about the five senses, such as what food that smells sweet, what looks nice, what feels soft, etc. After that, the teacher introduced the text by showing the title and illustrations in the text. The title of the text was "Miss Tiny Chef". It was about a little girl who loves cooking assisted by a wooden spatula. The text was completed by illustrations that could attract students' attention and give picture about the plot of the story. From seeing the title and illustrations, the students were directed to make a prediction about the text. In Reading stage, the students read each segment of the story in turn. After reading each segment, the teacher asked several questions related to the segment. After all segments have read, in Thinking phase, the students think about their predictions and verify whether their predictions were in line with the story. Lastly, the teacher revisited the text and asked students about the overall story.

\section{Guided reading}

Guided reading is a reading activity that involves a teacher working with a small group of students who demonstrate similar reading behaviors and can read similar levels of texts. Based on the observation, the teacher conducted this activity through four steps, namely introducing the text before reading, monitoring students' reading, doing discussion after students had finished their reading, and gave reinforcement. In this activity, the teacher was assigned to read about breakfast around country. Firstly, the teacher divided students into small groups. The teacher introduced the text by asking several questions, such as, "Do you usually eat breakfast? What is your favorite breakfast menu? and How do you like your breakfast?". Then, the teacher assigned students to read within their groups where they could 
discuss the text with their group members. Teacher's role was to assist students when facing difficulties. Next, teacher and students did a discussion of the text. The teacher started by asking about the content of the text. Then students may ask questions related to the text and they discuss together. Lastly, the teacher gave reinforcement. To students in form of rewards to those who were actively participated in the discussion.

\section{Multimedia-assisted reading}

Multimedia-assisted reading was another literacy activity found to be implemented in the classroom. It was found that the teachers used multimedia-assisted reading in form of electronic book with audio. Before conducting the reading activity, the teacher invited students to play a game called 'Mystery Box'. In this game, the teacher brought a box with several foods such as a pack of biscuits, an apple, an orange, a carrot, a bread, and a bar of chocolate. The teacher prepared these food as the topic of the text was healthy food. The teacher divided students into small groups based on their seating arrangement. One volunteer was called from each group to name three foods in the box without seeing it. So the students needed to touch the food and guess what food was it. The students got one point for each food that they guessed correctly. After they finished playing, the teacher showed the foods in the box and invited students to classify which food belong to healthy food and which ones belong to unhealthy food. The teacher then continued the activity by playing the electronic book about healthy food. In this reading activity, the students read the electronic book while listening to the audio.

\section{Thinking aloud}

A think-aloud is a teaching strategy in which a proficient reader (in this case, teacher) verbally reports his or her thinking about the text being read (Ness \& Kenny, 2016). In the implementation of this strategy in Jembatan Budaya primary school, the teacher first showed an illustration of the story being read. Then the teacher stated what she thought about the picture as well as the title of the story. The teacher also made a prediction of the story based on the title and the illustration. Then the teacher invited students to share their thoughts about the illustration and title of the text, as well as making predictions. After that the teacher read the text to students and asked several questions after a section.

\section{Reading aloud}

Read aloud is a reading activity to read a word, sentence, paragraph, or a text loudly. Reading aloud was found to be frequently used in Jembatan Budaya School to practice students' reading fluency. The teacher conducted this strategy by first introducing vocabulary related to the text. The text was about daily activities. The teacher first conducted a mime game about daily activities to attract students' attention. Then the teacher introduced the vocabulary by showing flashcards and invited students to read it together. After that the teacher introduced students to the text by showing the title. The teacher also asked students to look at the illustrations and asked them to predict the text. The teacher started the read aloud first, then, the teacher pointed out one student to continue the reading. It was done in turn after all sections in the text was finished.

\section{Dictation}

Dictation is an action of saying words aloud to be typed or written down. The result of the observation and interview showed that dictation was done on the $1^{\text {st }}$ grade. In this activity, the teacher said a word, then students wrote it on their book. The dictation was done on every topic to make students familiar with the vocabulary being taught. In addition, it was done to practice students' writing.

The dictation in Jembatan Budaya School was done in Discovery Learning setting which consists of stimulation, problem statement, data collection, data processing, and generalization. The topic being discussed was about animals. On the stimulation stage, the teacher read a chant about animals on the farm. Then, students repeated the chant after the teacher. After reading the chant, the teacher gave several questions related to the chant and the students the students answered the questions. On the next phase, problem statement, the teacher asked students whether they know tame animals. Teacher explained about tame and wild animals and gave some examples of them. The next phase was data collection and processing. In this phase, the teacher let students to collect information of wild animals from their books. Then, the teacher have students mention the name of wild animals. The teacher showed flashcards of wild animal and invited students to read it together. The teacher continued the activity by dictation. The teacher mentioned the name of animal, then students wrote it on their exercise book. After they have finished their works, the teacher checked it and gave feedback. The teacher gave chance to the fast learners to read books available in their classroom reading corner while waiting for the other students to finish their tasks. 


\section{Alphabet recognition}

Alphabet recognition was an activity in which teacher provided a pair of letter and students needed to recognize them. This activity was done on the $1^{\text {st }}$ and $2^{\text {nd }}$ grades. The pair of letter such as /f/ and $/ \mathrm{v} /, / \mathrm{m} /$ and $/ \mathrm{h} /, / \mathrm{y} /$ and $/ \mathrm{w} /$, and $/ \mathrm{h} /$ and $/ \mathrm{j} /$. The observed activity was differentiating consonant $/ \mathrm{y} /$ and $/ \mathrm{w} /$. This activity was inserted in TBLT method as one of the tasks assigned to students. In this activity, the teacher prepared a set of words that contain letter $/ y /$ or $/ w /$. Then the teacher showed each student a word that they read spontaneously. The examples of word set are presented in table 1 . This activity belongs to pre-task phase. It was done to make students were ready to follow the learning activity and to introduce the topic to be learnt. The example of alphabet recognition is presented in Table 2.

Table 2. Examples of alphabet recognition

\begin{tabular}{ccccc}
\hline you & berry & butterfly & swimming & fly \\
\hline walking & shower & watch & warm & yellow \\
\hline strawberry & berry & yacht & wearing & yogurt \\
\hline marshmallow & funny & water & wolf & sleepy \\
\hline
\end{tabular}

The first task assigned by teacher was differentiating between ' $y$ ' and ' $w$ '. With the same word set, the teacher approached students one by one and ask "Y or W?" the students answer by saying whether the word contains consonant ' $y$ ' or ' $w$ '. The activity was continued by grouping students into two groups based on the letter. After all students got the chance to read and differentiate the consonant, each of them got one word. Students who hold the word containing letter ' $w$ ' with them made a line at the back side of the class. Meanwhile, students who had word containing letter ' $y$ ' stayed at the front. The teacher checked one by one to make sure all students really know where they should be. The next task was 'circle or underline'. Teacher provided some sentences containing letter ' $w$ ' or ' $y$ '. Then, the teacher played an audio to be listened. Students needed to circle the consonant ' $w$ ' and underline the consonant ' $y$ '. In the post task activity, the teacher checked the students' work one by one and gave feedback on their works. The teacher assigned students to fill Self-assessment form in which students needed to circle their feeling about the learning activity. The teacher also gave reward in in form of sticker and put it in students' reward book.

\section{Writing}

Writing a simple story about students' daily activities was done on the $2^{\text {nd }}$ grade. Before assigning students to write, the teacher did several activities related to the topic. Since the topic was daily activities, the teacher challenged students to tell the time showed by teacher. Students were asked to come front one by one. Teacher showed a clock and set it. Then, students wrote the time on the board. This activity was done to introduce students with clock and how to read it. The next task was matching picture and filling the blank. In this activity, the teacher played a song entitled "From Morning to Night". Students need to listen to the song and sing together. After singing the song, the students matched the picture and the activities written in the song, for example: brush my teeth, do my homework, play, and go to bed. The activity was continued by filling the incomplete sentence. Students chose one of the word in the box to complete the sentence. After that, they discussed the answer with the teacher.

The activity was followed by writing a daily activity story. In this activity, the teacher gave an example to students of how their daily activity story would be. The example and students' work can be seen in figure 1 . The teacher provided some sentences as the examples of the activities done in the morning, afternoon, and evening. The story was also provided by a picture on each time category. On the post-task activity, the teacher gave rewards to students who did well during the class activity. The reward was given in form of stickers which are stuck in their reward book. The teacher ended the class by collecting students' works. Picture 1 represents the teacher's writing sample and student's work on writing. 


\begin{tabular}{|l|l|}
\multicolumn{2}{c}{ My Day } \\
\hline In the morning & Draw an activity here \\
1. I get up at 05:00. & \\
2. I eat breakfast at ..... & \\
3. & \\
\hline In the afternoon & \\
1. I do homework at... & \\
2. & \\
3. & \\
In the evening & \\
2. I eat dinner at... & \\
3. & \\
\hline
\end{tabular}

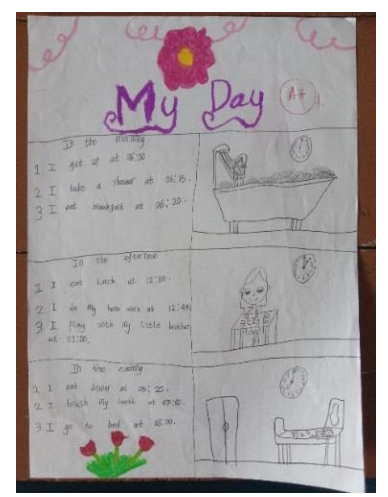

Picture 1. Teacher's writing sample and student's work on writing

\section{Discussions \\ Directed Reading - Thinking Activity (DRTA)}

The implementation of DRTA conducted by the teacher of Jembatan Budaya school was in line with Tierney et al. (in Chaemsai \& Rattanavich, 2016). They explained there are two main phases of implementing DRTA, namely directing the reading-thinking process and fundamental skill training. The Directing the reading-thinking process involves three steps: predicting, reading, and proving. In predicting step, the students receive a copy of the selection then the teacher directs students to study the title or picture on the text being read. The teacher asks students to predict the story and state their predictions. In reading step, the teacher directs students to read a segment of the story silently to check their predictions. The teacher is responsible to ensure that students read for meaning, observe reading performance, and help students who need help. In proving step, the students prove their predictions of the first segment. The teacher asks questions to guide students to examine and evaluate their predictions. Then students read the next segment of text, and with each new segment, continue the predicting-reading-proving cycle. The second phase - Fundamental skill training - entails reexamining the story, selected words or phrases, and pictures to develop students' reading-thinking abilities.

Chaemsai \& Rattanavich (2016) explained in this strategy, students are the center of learning, and the teacher takes role as a facilitator who assists students in connecting background knowledge and new information, promote understanding of reading content and encourage students' learning until they can do the activity independently. The use of DRTA has proven to be effective in improving students' reading comprehension, learning motivation, and learning achievement (Erliana, 2011; Maisarah, 2018; Setiartin, 2018). Students who were treated by DRTA showed a better understanding of a reading text and able to make predictions related to the contents of the text (Ardhian et al., 2020). Moreover, DRTA could improve students' reading comprehension and ethical awareness; it allows students to practice their reading skills, go through thinking processes, guess the content of unfamiliar texts, and connect their knowledge and experience to reading (Chaemsai \& Rattanavich, 2016).

\section{Guided reading}

These steps were consistent with Aitken et al. (2018) who mentioned four main steps to implement guided reading, namely: introducing the story, monitoring and reading, discussing the story after the first reading, and reinforcement. These steps provide motivation and coherence for students as well as giving opportunity to teacher to closely observe and respond to students' processing as they read independently. Reinforcement given in the end of the activity in form of rewards for the active students was important for students' literacy development. Rewards were important for students in the young ages. It was found that rewards could improve students' literacy and enthusiasm (Arisandi et al., 2018)

Guided reading enables teachers to support students in small groups in talking, reading and thinking their way purposefully through unfamiliar text ("Language and Literacy in the Foundation Stage," 2014). Guided reading has found effective to improve young learners' reading as it provides appropriate scaffolding for their reading development (Chaaya \& Ghosn, 2010). In addition, guided reading has found to increase students' reading fluency, accuracy, and comprehension (Heston \& Lelunann, 2010). Increased time spent in guided reading can have positive affect on students' ability; therefore, careful planning on guided reading need to be done to increase students' reading (Young, 2018).

In Guided reading activity, the teacher supports students to gain control over the process that lead to successful independent reading (Aitken et al., 2018). Teachers had positive perceptions towards the use of guided reading with their struggling readers and writers as it could help readers and writers 
develop their skills and motivation (McGrail et al., 2017). Similarly, students had good perceptions on using guided reading; it could help students to shape their reading comprehension (Hanke, 2014). In addition, Brown et al. (2016) found that guided reading had positively impacted students' motivation, reading comprehension, effort level, and understanding of the material. Makumbila \& Rowland (2016) found that guided reading helped to improve students' literacy engagement and motivation through levelled books, oral reading and group activities.

\section{Multimedia-assisted reading}

The use of multimedia in reading was found to affect young learner's literacy skills including vocabulary learning, story comprehension and reading engagement (Zhou \& Yadav, 2017). In addition, using multimedia in form of audio recording in reading activity was proven to improve reading fluency and comprehension (Friedland et al., 2017). Reading activity assisted by multimedia lets students to visualize the presented information in the text which is useful for them to decipher unfamiliar words, understand abstract ideas, and manipulate information acquired in order to answer comprehension questions (Abdul Samat \& Abdul Aziz, 2020). It could increase students' reading comprehension and learning outcomes (Khalidiyah, 2015). The use of multimedia in reading buddy program was proven to enhance vocabulary knowledge of the younger and older students (Silverman et al., 2017).

The use of games in classroom could create a fun environment and increase students' motivation to engage in the learning activities (Gozcu \& Caganaga, 2016). Children naturally love to play. They perceived it as an activity that involves their participation in doing something (Hatzigianni, 2014; Theobald et al., 2015). Play in classroom allows students to engage in purposeful activities through careful modeling of behavior and opportunities of imitation and manipulation (Ali et al., 2018). Play a game in inserted in learning activities can develop children's critical thinking skills, develops the foundation of intellectual, emotional, social, and physical skills, and increase children's confidence level (Kamarulzaman, 2015).

\section{Thinking aloud}

The thinking aloud strategy is characterized by the teacher modeling the thinking process by verbalizing thoughts while reading aloud for students. This strategy requires a reader to periodically stop to reflect on how a text is being processed and understood (Jackson, 2016). The main goal is to help students independently engage in similar cognitive process (Ness \& Kenny, 2016). In thinking aloud activity, the teacher expresses her thoughts to her students on how comprehension occurs while reading a text and improves their awareness of their comprehension processes. This strategy is important as teacher can be a model for students in order to transfer their thought processes about a text being read. Jackson (2016) argued that teacher can watch for the following cognitive processes while the students are engaged in the think-aloud activity: activate background knowledge, make predictions, form mental images, monitor comprehension progress, and use fix-up strategies as they interact with the text. It is important to model the comprehension process by thinking aloud because it gives the students the opportunity to see the thinking process involved when interacting with the text. Once the students have seen the different strategies used by the teacher while thinking aloud and have been given opportunities to practice utilizing those skills, they begin to internalize the process and are able to apply the skills on their own independently.

A study by Alzu'bi (2019) found that think aloud with appropriate text had a positive influence on the students' reading comprehension as it improves students' reading comprehension and motivation. Similarly, Al-Qahtani (2020) found the use of think-aloud strategy had improved students' reading comprehension skills and attitude. Students who were encouraged to Think-Aloud are more successful than other students in the traditional educational contexts. Jackson (2016) found that students who were treated using think-aloud strategy displayed higher gains in reading comprehension than the students who did not receive the think-aloud instruction. Ortlieb \& Norris (2012) found students who were treated by think-aloud strategy obtained higher gains on comprehension compared to students who were not. Students appeared engaged more than usual during the think-aloud sessions.

\section{Reading aloud}

Reading aloud was found to be effective in increasing children's vocabulary development and comprehension skill, enhances fluency and oral language, introduces students to diverse population or cultural diversity, and develops critical thinking and problem solving skills (Johnston, 2015). In addition, reading aloud was proven to make the students directly involve in classroom activity, and focus on the content of the text being read (Junaid, 2017). An effective read-aloud can enable students to learn about 
different types of conflicts and possible solutions as well as empathy and understanding for others (Johnston, 2015).

The more children are engaged during the read aloud experience, the greater benefit they get for their language and reading development (Acosta-Tello, 2019). The students' engagement can be increased by creating anticipation about the book by using the book cover, commenting on and asking questions about the characters, and making predictions. Read aloud is the most appropriate teaching strategy for vocabulary building; therefore vocabulary is very important on reading comprehension (Daud et al., 2019). Consistently, Lin (2014) found read-aloud has increased the word learning gain to students. Teachers' repeated story read-aloud can be an effective way to facilitate elementary school children's word learning in a context where English is a foreign language.

Implementing the read-aloud strategy have shown to have beneficial effects on the children's second language performance especially in developing their vocabulary. Thus, there is a sense of urgency for teachers and policy makers to understand the strengths of the read-aloud technique in enhancing vocabulary acquisition and learning so as to provide an enriching and stimulating environment that promotes and develops the English language amongst children (Omar, 2016). Reading aloud strategy is influential to improve students' fluency and pronunciation accuracy (Muhaimin, 2019).

\section{Dictation}

According to Gültekİn \& Guvey Aktay (2014), dictation is an important activity which enables students to gain language skills which will be required throughout life. It supports the development of writing and listening skills. In addition, it was found that dictation can help to determine the errors in literacy and check to what extent sounds are learnt (Gültekİn \& Guvey Aktay, 2014). In the context of young learners, dictation gives a significant effect on improvement of students' writing skill, increase students' vocabulary production and knowledge development (Christ et al., 2010; Wahyuni, 2014). Dictation also affects students' spelling in which spelling helps students in reading comprehension. therefore, dictation has indirect effect to reading comprehension (Johnson, 2013). Dictation could increase the number of ideas, quantity of the text, and the quality of the text produced by young learners (Arcon et al., 2017).

\section{Alphabet recognition}

Alphabet recognition was done to develop students' alphabet knowledge. In early literacy, alphabet knowledge refers to children's familiarity with letter forms, names, and corresponding sounds, which are important for their later reading and spelling abilities (Piasta \& Wagner, 2010). Alphabet knowledge is the ability to identify letters and understand that letters of the alphabet are a special category of visual graphics that can be individually named (Harris et al., 2015) it is considered as the best predictor of subsequent reading success for young children (Harris et al., 2015). Alphabet knowledge is critical in young learners' literacy as it allows children to make connections between letters and sounds, understand the language that classroom teachers use on a daily basis, and help them to have solid knowledge phonemic skills, such as blending and segmenting (Harris et al., 2015).

\section{Writing}

Writing is a fundamental part of language development, therefore it is important to develop writing skill to young learners as it allows young learners to practice new vocabulary and structures, allows a high degree of personalization and creativity, provides young learners to take risks and try out new language, and it allows teacher to diagnose learners' strengths and areas to develop in terms of vocabulary, structure, and spelling (Arnold \& Malcolm, 2018). Love et al. (2007) added that writing activities are salient part of quality literacy practices in early education settings as children learn important concepts about books and other forms of print in the world around them including alphabet systems through writing. It allows them to express themselves and communicate with others.

\section{Conclusion}

The literacy activity implemented on the Primary School are various; there were eight kinds of literacy activity, namely: Directed Reading - Thinking Activity (DRTA), guided reading, multimediaassisted reading, thinking aloud, reading aloud, dictation, alphabet recognition, and writing. This study provides a description about English literacy activities in Primary School conducted by teachers. Therefore, a suggestion is directed to English teachers to teach literacy to students since the early age as literacy is an important basis for students' future learning. Moreover, this school has been found to have various English literacy activities. Thus, this school can be a model that other schools may look at. However, this study is limited in terms of the context as it only focused on the literacy activities conducted 
on the $1^{\text {st }}, 2^{\text {nd }}$, and $3^{\text {rd }}$ grades. Thus, for further researchers who want to conduct research about literacy activities can explore more on the effectiveness of the implementation of literacy activities towards students' literacy skills as well as teacher and students' perception towards literacy activities at school.

\section{References}

Abdul Samat, M. S., \& Abdul Aziz, A. (2020). The Effectiveness of Multimedia Learning in Enhancing Reading Comprehension Among Indigenous Pupils. Arab World English Journal, 11(2), 290-302. https://doi.org/10.24093/awej/vol11no2.20.

Acosta-Tello, E. (2019). Reading aloud: engaging young children during a read aloud experience. Research in Higher Education Journal, 37, 1-7.

Aitken, J., Villers, H., \& Gaffney, J. S. (2018). Guided reading: Being mindful of the reading processing of new entrants in Aotearoa New Zealand primary schools. Teaching and Learning, 25-33. https://www.education.vic.gov.au/school/teachers/teachingresources/discipline/english/literac y/readingviewing/Pages/teachingpracguided.aspx.

Al-Qahtani, A. A. (2020). Investigating Metacognitive Think-Aloud Strategy in Improving Saudi EFL Learners' Reading Comprehension and Attitudes. English Language Teaching, 13(9), 50. https://doi.org/10.5539/elt.v13n9p50.

Ali, E., Kaitlyn M, C., Hussain, A., \& Akhtar, Z. (2018). the Effects of Play-Based Learning on Early Childhood Education and Development. Journal of Evolution of Medical and Dental Sciences, 7(43), 46824685. https://doi.org/10.14260/jemds/2018/1044.

Alzu'bi, M. (2019). The Impact of Think-Aloud on EFL Students' Reading Comprehension. Folio 19.

Arcon, N., Klein, P. D., \& Dombroski, J. D. (2017). Effects of Dictation, Speech to Text , and Handwriting on the Written Composition of Elementary School English Language Learners Language Learners. Reading \& Writing Quarterly, 33(6), 533-548. https://doi.org/10.1080/10573569.2016.1253513.

Ardhian, T., Ummah, I., Anafiah, S., \& Rachmadtullah, R. (2020). Reading and critical thinking techniques on understanding reading skills for early grade students in elementary school. International Journal of Instruction, 13(2), 107-118. https://doi.org/10.29333/iji.2020.1328a.

Arisandi, K. W. H., Padmadewi, N. N., \& Artini, L. P. (2018). Literacy and reward : teachers ' effort to build children reading habit. SHS Web of Conferences, 00018, 1-5. https://doi.org/10.1051/shsconf/20184200018.

Arnold, W., \& Malcolm, F. (2018). Writing and young learners. Teaching English _ British Council _ BBC. https://www.teachingenglish.org.uk/article/writing-young-learners.

Artini, L. P. (2017). Rich Language Learning Environment And Young Learners ' Literacy Skills In English. Lingua Cultura, 11(May), 19-24. https://doi.org/10.21512/lc.v11i1.1587.

August, D., \& Shanahan, T. (2010). Literacy Research. Journal of Literacy Research. https://doi.org/10.1080/1086296X.2010.503745.

Ayu, M., Diem, C. D., \& Vianty, M. (2017). Secondary School Students ' English Literacy : Use of Interactive Read Aloud Instructional Strategy. International Journal of Applied Linguistics \& English Literature, 292-299.

Brown, C. A., Danvers, K., \& Doran, D. T. (2016). Student perceptions on using guided reading questions to motivate student reading in the flipped classroom. Accounting Education, 25(3), 256-271. https://doi.org/10.1080/09639284.2016.1165124.

Cetin, Ö. Ș., Gulhan, M., \& Katranci, M. (2018). A Study on the Effect of Pre-School Education on Early Literacy Skills. International Online Journal of Educational Sciences, 10(5), 201-221.

Chaaya, D., \& Ghosn, I. K. (2010). Supporting young second language learners' reading through guided reading and strategy instruction in a second grade classroom in Lebanon. Educational Research and Reviews, 5(6), 329-337.

Chaemsai, R., \& Rattanavich, S. (2016). The Directed Reading-Thinking Activity (DR-TA) and the Traditional Approach Using Tales of Virtue based on His Majesty the King's Teaching Concepts in Seventh Grade Students' Reading Comprehension. English Language Teaching. https://doi.org/10.5539/elt.v9n9p18.

Christ, T., Wang, X. C., \& Chiu, M. M. (2010). Using story dictation to support young children 's vocabulary development: Outcomes and process. Early Childhood Research Quarterly, 26(January). https://doi.org/10.1016/j.ecresq.2010.06.002.

Creswell, J. W. (2012). Educational Research: Planning, Conducting and Evaluating Quantitative and Qualitative Research (4th ed.). Pearson.

Daud, Z., Kazi, A. S., \& Kalsoom, T. (2019). Vocabulary Building through Read-Aloud Strategy of Primary Level Students in Pakistan. Pakistan Journal of Distance \& Online Learning, 5(II), 247-264. 
Dewi, I. A. M., Padmadewi, N. ., \& Artini, L. . (2018). Primary Literacy Program : Integrating Reading and Writing in The Classroom. Advances in Social Science, Education and Humanities Research, 173(May). https://doi.org/10.2991/icei-17.2018.38.

Erliana, S. (2011). Improving reading comprehension through directed reading-thinking activity (DRTA) strategy. Journal on English as a Foreign Language, 1(1), 49. https://doi.org/10.23971/jefl.v1i1.36.

Friedland, A., Gilman, M., Johnson, M., \& Demeke, A. (2017). Does Reading-While-Listening Enhance Students' Reading Fluency? Preliminary Results from School Experiments in Rural Uganda. Journal of Education and Practice, 8(7), 82-95.

Gozcu, E., \& Caganaga, C. K. (2016). The importance of using games in EFL classrooms. Cypriot Journal of Educational Sciences, 11(3), 126. https://doi.org/10.18844/cjes.v11i3.625.

Gültekİn, M., \& Guvey Aktay, E. (2014). Dictation Activities in Reading and Writing Instruction. Inonu University Journal of the Faculty of Education, 15(2), 19-22. https://doi.org/10.17679/iuefd.43574.

Hanke, V. (2014). Guided reading: Young pupils' perspectives on classroom practice. Literacy, 48(3), 136143. https://doi.org/10.1111/lit.12019.

Harmer, J. (2007). How to Teach English (2nd ed.). Pearson.

Harosid, H. (2017). Kurikulum 2013 Revisi 2017. https://dosen.ikipsiliwangi.ac.id/wpcontent/uploads/sites/6/2018/09/Gambaran-Umum-K13-Revisi-2017.pdf.

Harris, K. I., Kinley, H. L., \& Cook, A. (2015). Promoting Alphabet Knowledge Using Peer-Mediated Intervention: A Dynamic Duo for Early Literacy Development. 1-14. https://doi.org/10.1177/1096250615586027.

Hatzigianni, M. (2014). "I Like Computers but My Favourite Is Playing outside with My Friends": Young Children's Beliefs about Computers. International Research in Early Childhood Education, 5(1), 83102. http://search.ebscohost.com/login.aspx?direct=true\&db=eric\&AN=EJ1151023\&site=ehostlive NS -.

Heston, K., \& Lelunann, J. (2010). The Effects of Guided Reading Instruction on Students' Fluency, Accuracy, and Comprehension at Woodview Elementary School.

Hill, S. (2011). Early Literacy. In Family and Community Engagement Research Compedium (pp. 9-33). https://doi.org/10.1007/978-94-007-0573-9_5.

Jackson, V. (2016). Applying the think-aloud strategy to improve reading comprehension of science content. Current Issues in Education, 19(2), 1-35.

Jensen, L. (2001). Planning Lessons. In M. Celce-Murcia (Ed.), Teaching English as a second or foreign language (3rd ed., p. 401). Thomson Learning. https://doi.org/10.5958/22497137.2017.00044.1.

Johnson, M. M. (2013). The Relationship Between Spelling Ability And Reading Fluency And Comprehension In Elementary Students. Northern Michigan University.

Johnston, V. (2015). The power of the read aloud in the age of the common core. Open Communication Journal, 9, 34-38. https://doi.org/10.2174/1874916X01509010034.

Junaid, A. (2017). The Effectiveness of Reading Aloud to Improve the Students 'Vocabulary Mastery at the Second Grade of SMPN 3 Parangloe Alauddin State Islamic University of Makassar.

Kamarulzaman, W. binti. (2015). Affect of Play on Critical Thinking: What are the Perceptions of Preservice Teachers. International Journal of Social Science and Humanity, 5(12), 1024-1029. https://doi.org/10.7763/ijssh.2015.v5.598.

Khalidiyah, H. (2015). The Use of Animated Video in Improving Students' Reading Skill (A QuasiExperimental Study of Seventh Grade Student at A Junior High School in Jalancagak, Subang). Journal of English and Education, 3(1), 1-21.

Language and Literacy in the Foundation Stage. (2014). In Early Years Literacy Interboard Group Publication.

Lin, L. C. (2014). Learning word meanings from teachers' repeated story read-aloud in EFL primary classrooms. English Language Teaching, 7(7), 68-81. https://doi.org/10.5539/elt.v7n7p68.

Love, A., Burns, S., \& Buell, M. J. (2007). Writing Empowering Literacy. National Association for the Education of Young Children.

Maisarah, S. (2018). Using Direct Reading Thinking Activity (DRTA) to teach reading comprehension for eleventh grade students. 1(2). https://www.uam.es/gruposinv/meva/publicaciones jesus/capitulos_espanyol_jesus/2005_motivacion para el aprendizaje Perspectiva alumnos.pdf\%0Ahttps://www.researchgate.net/profile/Juan_Aparicio7/publication/253571379 _Los_estudios_sobre_el_cambio_conceptual_.

Makumbila, M. P., \& Rowland, C. B. (2016). Improving South African third graders' reading skills: Lessons 
learnt from the use of Guided Reading approach. South African Journal of Childhood Education, 18. http:// dx.doi.org/10.4102/sajce. v6i1.367.

McGrail, E., Rieger, A., \& Doepker, G. (2017). Pre-Service Teachers' Perceptions about the Effectiveness of the TOON Comic Books in Their Guided Reading Instruction. Georgia Educational Researcher, 14(1). https://doi.org/10.20429/ger.2017.140101.

Montoya, S. (2018). Defining literacy: UNESCO (Issue October).

Muhaimin, A. (2019). The use of reading aloud strategy to improve students' fluency and pronunciation accuracy in reading skills of the eight grade at MTs NU Aswaja Tenggaran.

Muhajang, T., \& Pangestika, M. D. (2018). Pengaruh Literasi Informasi Terhadap Efektivitas Belajar Siswa. Pedagonal : Jurnal Ilmiah Pendidikan, 2(2), 15-22. https://doi.org/10.33751/pedagog.v2i2.849.

Nesari, A. J., \& Heidari, M. (2014). The Important Role of Lesson Plan on Educational Achievement of Iranian EFL Teachers' Attitudes. International Journal of Foreign Language Teaching \& Research, 2(5), 25-31. http://jfl.iaun.ac.ir/article_10884_43a5ff2bb7fbd6998f091eb726f80104.pdf.

Ness, M., \& Kenny, M. (2016). Improving the Quality of Think-Alouds. Reading Teacher, 69(4), 453-460. https://doi.org/10.1002/trtr.1397.

OECD. (2018). Programme for International Student Assessment (PISA) Result from PISA 2018. In OECD. http://www.oecd.org/pisa/ Data.

Omar, A. (2016). Read-Aloud Technique to Enhance Pre-School Children's Vocabulary in a Rural School in Malaysia. International Journal of Early Childhood Education and Care, 5(2001), 17-27.

Ortlieb, E., \& Norris, M. (2012). Using the think-aloud strategy to bolster reading comprehension of science concepts. Current Issues in Education, 15(1), 1-10.

Oueini, H., Bahous, R., \& Nabhani, M. (2008). Impact of Read-Aloud in the Classroom: a Case Study. The Reading Matrix, 8(1), 19.

Padmadewi, N. N., \& Artini, L. P. (2018). Literasi di Sekolah: Dari Teori ke Praktik (N. Prasada (ed.)). Penerbit Nilacakra.

Padmadewi, N. N., Artini, L. P., Budiarta, L. G. ., \& Apriliadewi, P. A. R. (2020). Primary Literacy Activities in Basic Education in Bali: Describing Implication on Children Reading and Writing in EFL. Advances in Social Science, Education and Humanities Research, 394(ICIRAD 2019), 184-189. https://doi.org/10.2991/assehr.k.200115.030.

Padmadewi, N. N., Artini, L. P., \& Nitiasih, P. K. (2018). Techniques for Building Character and Literacy for 21st Century Education. Advances in Social Science, Education and Humanities Research, 173(May), 250-253. https://doi.org/10.2991/icei-17.2018.65.

Pérez-Ferra, M., Quijano-López, R., \& García-Martínez, I. (2020). Impact of educational habits on the learning of 3-6 year old children from the perspective of early childhood education teachers. Sustainability (Switzerland), 12(11). https://doi.org/10.3390/su12114388.

Piasta, S. B., \& Wagner, R. K. (2010). Developing Early Literacy Skills: A Meta-Analysis of Alphabet Learning and Instruction. Read Res $Q, \quad 45(1), \quad 1-7$. https://doi.org/10.1598/RRQ.45.1.2.Developing.

Ratri, Y. (2015). Student factor influencing Indonesian student reading literacy based on PIRLS data 2011. Journal of Education, 8(1).

Rittner, M. A. (2018). Impact of Literacy on Student Readiness in Math and Science Classroom.

Rockets, R. (2019). Directed Reading Thinking Activity (DRTA). Reading Rockets. https://www.readingrockets.org/strategies/drta.

Rusu, C., Wallace, R. 'Dickie,' Costea, V., Coman, M., Pop, A. S. and C., \& Navsaria, D. (2017). Attitudes and practices of pre-reading and early childhood literacy promotion among family physicians in Romania. Journal of Early Childhood Literacy, O(0), 1-28. https://doi.org/10.1177/1468798417728402.

Setiartin, T. (2018). Increasing Ability to Understand Fairy Tale Through Directed Reading Thinking Activity (DRTA) Strategy. Cakrawala Linguista, 1(1), 1. https://doi.org/10.26737/cling.v1i1.491.

Silverman, R., Kim, Y. S., Hartranft, A., Nunn, S., \& McNeish, D. (2017). Effects of a multimedia enhanced reading buddies program on kindergarten and Grade 4 vocabulary and comprehension. Journal of Educational Research, 110(4), 391-404. https://doi.org/10.1080/00220671.2015.1103690.

Theobald, M., Danby, S., Einarsdóttir, J., Bourne, J., Jones, D., Ross, S., Knaggs, H., \& Carter-Jones, C. (2015). Children's perspectives of play and learning for educational practice. Education Sciences, 5(4), 345-362. https://doi.org/10.3390/educsci5040345.

Wahyuni, N. S. (2014). The Effect of Using Dictation Technique on Students' Writing Ability at SMP Karya Bhakti Kasiyan in the 2013/2014 Academic Year.

Wiedarti, P., Kisyani-Laksono, Retnaningdyah, P., Dewayani, S., Muldian, W., Sufyadi, Susanti, Roosaria, D. R., Faizah, D. D. U., Sulastri, Rahmawan, N., Rahayu, E. S., Yusuf, R. A., \& Antoro, B. (2018). Desain 
Induk Gerakan Literasi Sekolah (P. Wiedarti \& Kisyani-Laksono (eds.); 2nd ed.). Direktorat Jenderal Pendidikan Dasar dan Menengah Kementerian Pendidikan dan Kebudayaan.

Young, C. (2018). Increased frequency and planning: A more effective approach to guided reading in Grade 2. Journal of Educational Research, 112(1), 121-130. https://doi.org/10.1080/00220671.2018.1451814.

Zhou, N., \& Yadav, A. (2017). Effects of multimedia story reading and questioning on preschoolers' vocabulary learning, story comprehension and reading engagement. Educational Technology Research and Development, 65(6), 1523-1545. https://doi.org/10.1007/s11423-017-9533-2. 